\title{
Poszukiwanie informacji na temat choroby oraz satysfakcja z informacji otrzymanej w grupie chorych na nowotwory hematologiczne i nowotwory lite
}

\author{
Anna Kieszkowska-Grudny ${ }^{1,2}$, Monika Rucińska ${ }^{3,4}$, Aleksandra Sopel5, \\ Mateusz Szmit ${ }^{3}$, Henryka Kubaj ${ }^{1}$, Olga Wilk ${ }^{3}$, Robert Ciesak ${ }^{3}$
}

Cel pracy. Większość pacjentów chorych na nowotwory doświadcza problemów natury nie tylko medycznej, ale też psychologicznej, duchowej, socjalnej. Bardzo często pacjenci i ich bliscy czują się zagubieni i zdezorientowani, nie wiedząc, gdzie i od kogo mogliby otrzymać dodatkowe informacje i wsparcie. Celem badania była identyfikacja sposobu poszukiwania przez chorych na nowotwory lite i nowotwory hematologiczne informacji i profesjonalistów, do których mogliby się zwrócić o pomoc, oraz ocena satysfakcji z otrzymywanej informacji i wsparcia.

Materiał i metody. W badaniu wzięło udział 219 chorych (111 chorych na nowotwory lite, mediana wieku 62 lata, i 108 chorych na nowotwory hematologiczne, mediana wieku 59 lat). Jedna trzecia osób badanych miała 65 i więcej lat. Wśród badanych było 53\% kobiet i 47\% mężczyzn. Chorzy wypełniali autorski kwestionariusz, przygotowany specjalnie na potrzeby tego badania.

Wyniki. Emocje pozytywne znacząco dominowały nad emocjami negatywnymi. Emocje negatywne znamiennie częściej pojawiały się w grupie chorych na nowotwory hematologiczne. Większość chorych była zainteresowana otrzymaniem informacji, głównie od lekarzy ( $92 \%$ respondentów) i pielęgniarek (76\% respondentów). Natomiast aż $77 \%$ chorych nie szukało informacji u psychologów i psychoterapeutów. Bardziej zainteresowanymi poszukiwaniem informacji u psychologów były osoby doświadczające więcej negatywnych emocji. Z pomocy pracodawcy/wychowawcy i pracownika socjalnego w zdobywaniu informacji pacjenci korzystali bardzo rzadko (odpowiednio 7\% i 8\% ankietowanych). Prawie wszyscy respondenci byli usatysfakcjonowani informacjami uzyskanymi od lekarzy i pielęgniarek, ale tylko połowa - informacjami uzyskanymi od psychologa/psychoterapeuty i rehabilitanta/fizjoterapeuty, i jeszcze mniej (42\% ankietowanych) od organizacji pacjenckich.

Wnioski. Pacjenci nie szukają aktywnie informacji i wsparcia, nie wiedzą też, kogo o nie prosić. Najczęściej kierują pytania do lekarzy i personelu pielęgniarskiego. Wskazane jest tworzenie wielodyscyplinarnych zespołów opieki i wsparcia w ośrodkach onkologicznych oraz dokładne informowanie pacjentów o zakresie pomocy, z którego mogą korzystać. Niezbędne są także specjalistyczne szkolenia poszczególnych członków zespołu w umiejętnościach nawiązywania dobrych profesjonalnych kontaktów z pacjentami.

\section{Assessment using a questionnaire of patient satisfaction with information on cancer provided} by doctors and nurses and other healthcare professionals

Aim. Most patients suffering from cancer experience not only medical, but also psychosocial and spiritual problems. Very often patients and their family are lost in the healthcare system and do not know where and from whom

\footnotetext{
${ }^{1}$ Europejskie Centrum Zdrowia Otwock

${ }^{2}$ Minds of Hope w Warszawie

${ }^{3}$ Katedra Onkologii

Uniwersytet Warmińsko-Mazurski w Olsztynie

${ }^{4}$ Oddział Radioterapii
}

ZOZ MSW z Warmińsko-Mazurskim Centrum Onkologii w Olsztynie

${ }^{5}$ Centrum Onkologii — Instytut im. Marii Skłodowskiej-Curie w Warszawie 
to obtain reliable information. The aim of this study was to identify various approaching in seeking information and differences in satisfaction with healthcare, taking into account types of cancer.

Material and method. Two hundred nineteen patients were included to the study (111 patients with solid tumours, median age 62 years and 108 haematological patients, median age 59 years). One third of patients were over 64 year old. There were $53 \%$ women and $47 \%$ men in the study group. All patients completed a questionnaire specially prepared for this study.

Results. Negative emotions appeared significantly more often in patients with haematological malignancies. Most of the patients were interested in receiving information mainly from doctors ( $92 \%$ of responders) and from nurses (76\% of responders). Up to $77 \%$ of patients did not seek information from psychologists and psychotherapists. Those interested in searching for information from psychologists were patients experiencing negative emotions. Patients very rarely used the employer/educator and a social worker for obtaining information $(7 \%$ and $8 \%$ responders, respectively). Almost all patients were satisfied with the information received from the doctors and nurses, but only half were satisfied with the information received from the psychologist/psychotherapist and physiotherapist and even fewer ( $42 \%$ of respondents) from patient's organisations.

Conclusions. Patients are not actively looking for information and support. They also do not know whom to ask. Most frequently they ask professional questions of the doctors and nursing staff. It is recommended to create a multidisciplinary care and support teams at oncology centers, and accurately inform patients about the types of support that they can use. Specialized trainings of individual team members in the skills of good professional contacts with patients are also required.

NOWOTWORY Journal of Oncology 2015; 65, 4: 281-291

Słowa kluczowe: nowotwory lite, nowotwory hematologiczne, komunikacja lekarz-pacjent, informacja o chorobie, emocje w chorobie nowotworowej

Key words: solid tumors, hematological tumors, doctor-patient communication, information about the disease, emotions in cancer patients

\section{Wstęp}

Zachorowalność na nowotwory ciągle wzrasta. W okresie od 2008 r. do 2012 r. liczba nowych zachorowań na świecie wzrosła z 12,7 mln do 14,1 mln. Prognozuje się, że w ciągu najbliższych dwóch dekad liczba ta może się prawie podwoić [1]. Rozpoznanie choroby nowotworowej jest dużym stresem i poważnym kryzysem zarówno dla samego chorego, jak i jego bliskich. Pacjenci i ich bliscy stają przed nowymi trudnościami, zadaniami i wyzwaniami. Często nie rozumieją istoty choroby, boją się nieznanego i obarczonego wieloma powikłaniami leczenia. Żyją w ciągłym poczuciu zagrożenia zdrowia i życia, dlatego potrzebują nie tylko informacji o samej chorobie i leczeniu, ale i wsparcia uwzględniającego aspekty pozamedyczne.

Pacjenci bardzo często są zagubieni w systemie opieki i nie wiedzą, gdzie uzyskać potrzebne informacje, lub nie mają śmiałości, by pytać. Niewiedza prowadzi do dodatkowego stresu. Poza tym pacjent zdezorientowany, zagubiony i niepewny może nie odczuwać satysfakcji z kontaktów z personelem medycznym i nieadekwatnie postrzegać oraz oceniać otrzymywaną opiekę medyczną i pozamedyczną. U osób chorych na nowotwory pojawia się dystres, który może być powiązany np. ze smutkiem, poczuciem beznadziejności, zaniepokojeniem, poczuciem winy, lękiem, napadami paniki, zniechęceniem, depresją itp. [2]. Chorzy stają w obliczu konfrontacji z poważnymi egzystencjalnymi problemami, zdając sobie sprawę z własnej śmiertelności [3, 4], ponadto muszą się zmierzyć z nowymi, skomplikowanymi i często niezrozumiałymi informacjami, które chcą i muszą zrozumieć i przyswoić. Chorzy demonstrują różne style zachowań związane z poszukiwaniem informacji o chorobie i leczeniu — bardziej aktywne lub bardziej unikowe [5, 6]. System opieki medycznej daje pacjentowi dostęp do różnych profesjonalistów, którzy mogą stanowić źródło informacji i wsparcia dla chorych. Podstawowym źródłem wiedzy są oczywiście lekarze i pielęgniarki, ale ważną rolę w tej mierze powinni spełniać także psychologowie, psychoonkolodzy, psychoterapeuci, rehabilitanci/fizjoterapeuci, duchowni, pracownicy socjalni, dietetycy, stowarzyszenia i organizacje pacjentów. Ponadto bezpośrednim źródłem informacji może być rodzina, przyjaciele, znajomi, inni pacjenci, a nierzadko i pracodawcy - między innymi w sytuacji, gdy chory ubiega się o różnego rodzaju zasiłki, zaświadczenia, czy też przedstawia zwolnienia lekarskie. Niestety, chorzy bardzo często nie wiedzą, gdzie szukać informacji, u kogo jaką informację mogą otrzymać, kto jest dostępny w placówce, w której się leczą, a jakiego wsparcia i u kogo można szukać poza ośrodkiem onkologicznym. Tymczasem odpowiednia, rzetelna i zrozumiała dla pacjenta informacja przekazana przez lekarza i/lub innego profesjonalistę powoduje lepsze 
zrozumienie natury choroby i wyeliminowanie pochodzącej z niezweryfikowanych źródeł, często wzmagającej wręcz lęk i inne emocje, nieprawdziwej wiedzy. Właściwa wiedza pacjenta na temat choroby i dobre zrozumienie procedur medycznych poprawia współpracę z personelem medycznym i zwiększa prawdopodobieństwo stosowania się pacjenta do zaleceń lekarskich. Zwiększa również zaufanie do lekarza, zaangażowanie pacjenta i jego rodziny w proces leczenia, a nawet zmniejsza odczuwanie skutków ubocznych procedur diagnostycznych i terapeutycznych [7-9]. Pacjent, który nie uzyskuje żadnej informacji od personelu medycznego, bądź otrzymuje informację niejasną i niezrozumiałą, będzie prawdopodobnie częściej poszukiwał wiedzy w innych, często niesprawdzonych źródłach poza systemem opieki medycznej. Dodatkowym efektem dobrego zrozumienia natury choroby i jej terapii jest mniejsza potrzeba pacjenta do sięgania po niekonwencjonalne metody leczenia [10].

\section{Cele badania}

Jak dotąd nie było doniesień porównujących obszary związane z poszukiwaniem informacji nt. choroby pomiędzy osobami chorującymi na nowotwory hematologiczne i nowotwory lite. Nieliczne są również prace, które wprost odnoszą się do stylów pozyskiwania informacji przez chorych na nowotwory. Podstawowym celem badania było zidentyfikowanie tego, w jaki sposób chorzy poszukują informacji oraz do kogo częściej, a do kogo rzadziej zwracają się z pytaniami związanymi z chorobą. Ponadto zamiarem było porównanie emocji pojawiających się w obu grupach, jak również znalezienie związków pomiędzy miejscem poszukiwania informacji w zależności od problemów, z którymi zmagali się chorzy.

\section{Materiał i metoda}

Do udziału w badaniu zaproszono chorych na nowotwory hematologiczne i guzy lite, będących w trakcie aktywnego leczenia przeciwnowotworowego w dwóch wysokospecjalistycznych placówkach o profilu onkologicznym oraz dwóch o profilu hematologicznym, zlokalizowanych na terenie województwa mazowieckiego oraz warmińsko-mazurskiego. We wszystkich ośrodkach pacjenci mieli do dyspozycji psychologów (w tym psychoonkologów), fizjoterapeutów, kapelanów szpitalnych. Każdy z ośrodków deklarował współpracę z organizacjami pacjenckimi.

Badanie było dobrowolne i anonimowe, chorzy wyrazili pisemną zgodę na udział w badaniu.

Badanie miało charakter kwestionariuszowy, nieinterwencyjny. Chorzy wypełniali kwestionariusz przygotowany specjalnie na potrzeby tego badania, obejmujący kilka kategorii pytań. Pytania dotyczyły: a) danych demograficznych, b) problemów socjalno-społecznych, c) stopnia zainteresowania poszukiwaniem informacji na temat choroby i leczenia, d) oceny satysfakcji z otrzymywanej informacji. Dodatkowo chorzy wypełniali kwestionariusz PANAS (Skala Pozytywnego i Negatywnego Afektu), składający się z 20 pozycji dotyczących emocji pozytywnych i negatywnych (po 10 pozycji w każdej kategorii).

Analiza statystyczna z użyciem IBM SPSS Statistics wersja 22 obejmowała statystyki opisowe, częstości, różnice średnich mierzonych za pomocą testu t-Studenta oraz korelacje przy użyciu współczynnika R-Pearsona. Wartości $\mathrm{p}<0,05$ były istotne statystycznie.

\section{Wyniki}

W badaniach prowadzonych od stycznia do października 2014 r. wzięło udział 219 chorych (111 chorych na nowotwory lite w wieku 37-80 \pm 10,24 lat, średnia wieku 61 lat, mediana 62 lata i 108 chorych na nowotwory hematologiczne W wieku: 20-85 \pm 17,86 lat, średnia wieku 55 lat, mediana 59 lat). Jedna trzecia osób badanych miała 65 i więcej lat. Wśród badanych było 53\% kobiet i 47\% mężczyzn (wśród pacjentów chorych na nowotwory lite 54\% kobiet i 46\% mężczyzn, w grupie hematologicznej 52\% kobiet i 48\% mężczyzn). Ponad połowa pacjentów miała wykształcenie średnie lub wyższe (średnie 47\%, wyższe 28\%). Większość osób biorących udział w badaniu pozostawało w stałym związku. Jedna trzecia respondentów była mieszkańcami małych miast, tyle samo mieszkało na wsi. $85 \%$ badanych miało dzieci (92\% chorych na nowotwory lite i 77\% chorych na nowotwory hematologiczne). Prawie $88 \%$ osób z grupy badanej miało rodzeństwo. Szczegóły dotyczące danych demograficznych respondentów obu grup przedstawia tabela I.

U ponad połowy chorych pogorszyła się sytuacja finansowa w związku z chorobą. W grupie aktywnej zawodowo lub nadal uczących się (łącznie 58\% respondentów), 63\% chorych musiało całkowicie lub prawie całkowicie zaprzestać aktywności zawodowej lub nauki z powodu choroby. Dwie trzecie badanych chorych czuło się częściowo lub całkowicie ograniczonych w wykonywaniu codziennych czynności. Trudności związane z wykonywaniem pracy zawodowej znamiennie częściej dotyczyły chorych na nowotwory lite $(t=2,208 ; d f=215 ; p=0,028)$. Ponadto chorzy ci znamiennie częściej martwili się o swoją pracę lub szkołę $(t=3,305 ; d f=217 ; p=0,001)$. $Z$ kolei $u$ chorych na nowotwory hematologiczne istotnie częściej pojawiało się poczucie ograniczenia samodzielności z powodu choroby $(t=2,470 ; d f=210 ; p=0,014)$. Pacjenci chorzy na nowotwory hematologiczne częściej niż chorzy na nowotwory lite mieli poczucie, że z powodu choroby różnią się od innych ludzi $(t=1,970 ; d f=209 ; p=0,050)$. Respondenci leczeni $z$ powodu nowotworów litych zdecydowanie częściej niż osoby chorujące na nowotwory hematologiczne mogli otwarcie rozmawiać z partnerką/partnerem o wpływie choroby na ich wspólne życie i relacje $(t=2,800 ; d f=212 ; p=0,006)$. 
Tabela I. Charakterystyka chorych z podziałem na rodzaje choroby nowotworowej: nowotwory lite vs nowotwory hematologiczne

\begin{tabular}{|c|c|c|c|c|c|c|c|}
\hline & & \multicolumn{2}{|c|}{ Chorzy na nowotwory lite } & \multicolumn{2}{|c|}{$\begin{array}{c}\text { Chorzy na nowotwory } \\
\text { hematologiczne }\end{array}$} & \multicolumn{2}{|c|}{ Sumarycznie } \\
\hline & & liczba & $\%$ & liczba & $\%$ & liczba & $\%$ \\
\hline \multicolumn{2}{|c|}{ Liczba osób badanych } & 111 & 50,7 & 108 & 49,3 & 219 & 100 \\
\hline \multirow[t]{2}{*}{ Płeć } & kobiety & 60 & 54,1 & 56 & 51,9 & 116 & 53,0 \\
\hline & mężczyźni & 51 & 45,9 & 52 & 48,1 & 103 & 47,0 \\
\hline \multirow[t]{4}{*}{ Wiek (lata) } & minimum & 37 & & 20 & & 20 & \\
\hline & maksimum & 80 & & 85 & & 80 & \\
\hline & średnia & 60,6 & & 55,1 & & 57,9 & \\
\hline & mediana & 62,0 & & 59,0 & & 60,0 & \\
\hline \multirow[t]{4}{*}{ Wykształcenie } & wyższe & 23,0 & 20,7 & 38,0 & 35,2 & 61,0 & 24,7 \\
\hline & średnie & 56,0 & 50,5 & 46,0 & 42,6 & 102,0 & 46,6 \\
\hline & podstawowe i zawodowe & 32,0 & 28,8 & 22,0 & 20,4 & 54,0 & 27,8 \\
\hline & brak danych & & & 2,0 & 1,8 & 2,0 & 0,9 \\
\hline \multirow[t]{5}{*}{ Stan cywilny } & w stałym związku & 72,0 & 64,9 & 80,0 & 74,1 & 152,0 & 69,4 \\
\hline & wdowiec/wdowa & 17,0 & 15,3 & 8,0 & 7,4 & 25,0 & 11,4 \\
\hline & w separacji/po rozwodzie & 13,0 & 11,7 & 8,0 & 7,4 & 21,0 & 9,6 \\
\hline & kawaler/panna & 9,0 & 8,1 & 10,0 & 9,3 & 19,0 & 8,7 \\
\hline & brak danych & & & 2,0 & 1,8 & 2,0 & 0,9 \\
\hline \multirow[t]{5}{*}{$\begin{array}{l}\text { Miejsce } \\
\text { zamieszkania }\end{array}$} & $\begin{array}{l}\text { miasta ponad } 200 \text { tys. } \\
\text { mieszkańców }\end{array}$ & 21,0 & 18,9 & 34,0 & 31,5 & 55,0 & 25,1 \\
\hline & $\begin{array}{l}\text { miasta } 50-200 \text { tys. } \\
\text { mieszkańców }\end{array}$ & 7,0 & 6,3 & 18 & 17 & 25,0 & 11,4 \\
\hline & $\begin{array}{l}\text { miasta do } 50 \text { tys. } \\
\text { mieszkańców }\end{array}$ & 42,0 & 37,8 & 24,0 & 22,2 & 66,0 & 30,2 \\
\hline & wieś & 41,0 & 36,9 & 28,0 & 25,9 & 69,0 & 31,5 \\
\hline & brak danych & & & 4,0 & 3,7 & 4,0 & 1,8 \\
\hline \multirow{2}{*}{$\begin{array}{l}\text { Aktywni } \\
\text { zawodowo/ } \\
\text { /szkolnie }\end{array}$} & aktywny zawodowo/szkolnie & 50,0 & 45,0 & 78,0 & 72,2 & 128,0 & 58,4 \\
\hline & $\begin{array}{l}\text { nieaktywny zawodowo/ } \\
\text { /szkolnie }\end{array}$ & 61,0 & 55,0 & 30,0 & 27,8 & 91,0 & 41,6 \\
\hline \multirow[t]{2}{*}{ Rodzina } & dzieci & 91,0 & 91,9 & 78 & 74,1 & 33,0 & 84,9 \\
\hline & rodzeństwo & 88,0 & 89,2 & 84 & 87,0 & 26,0 & 88,1 \\
\hline
\end{tabular}

Natomiast wzrost wiary i praktyk religijnych w znacząco większym stopniu zaobserwowano w grupie chorych na nowotwory hematologiczne w porównaniu z pozostałymi pacjentami $(t=3,461 ; d f=217 ; p=0,001)$. Chorzy ci częściej modlili się i kontemplowali.

Zdecydowana większość chorych (zarówno w grupie onkologicznej, jak i hematologicznej), była zainteresowana otrzymaniem informacji na temat swojego stanu zdrowia, w pierwszej kolejności od lekarzy (92\%) i pielęgniarek (76\%), a także od najbliższych członków rodziny (57\%) i przyjaciół (33\%). Najmniej oczekują chorzy pod tym względem od pracodawców lub wychowawców (w zależności od tego, czy są aktywni zawodowo, czy w trakcie nauki), pracowników socjalnych i grup wsparcia. Okazało się również, że aż 77\% chorych (80\% w grupie onkologicznej i $74 \%$ w grupie hematolo- gicznej) w ogóle nie szuka informacji u psychologów i psychoterapeutów. Szczegółowe wyniki przedstawia tabela II, przedstawienie graficzne ważności roli poszczególnych profesjonalistów i osób towarzyszących jako źródła informacji - rycina 1.

Wyniki badania wskazują, że najmniejszej satysfakcji doświadczają chorzy w związku z otrzymywaniem informacji od pracodawców i wychowawców, aż 71\% respondentów poszukujących tego typu informacji jest nieusatysfakcjonowanych (odpowiedzi „zdecydowanie nie" i „raczej nie”). Niezbyt satysfakcjonujące respondentów są także informacje otrzymywane od pracowników socjalnych (63\% nieusatysfakcjonowanych) i — co szczególnie ciekawe - grup wsparcia (58\% nieusatysfakcjonowanych). Natomiast prawie wszystkie osoby, które były zainteresowane poszukiwaniem 


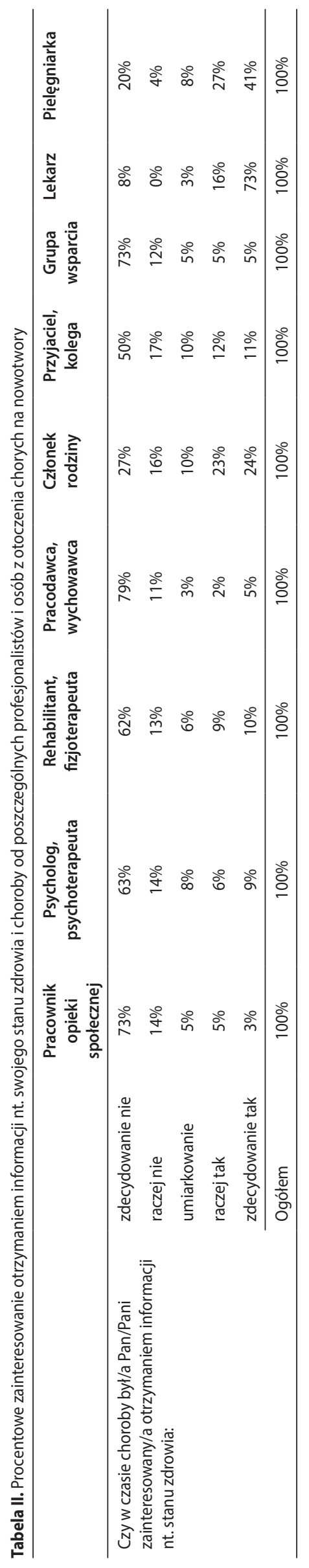

informacji u lekarzy (96\% respondentów) i pielęgniarek (91\%), były usatysfakcjonowane uzyskanymi informacjami (odpowiedzi "raczej tak" i „zdecydowanie tak"). Połowa respondentów była usatysfakcjonowana informacjami uzyskanymi od psychologa/psychoterapeuty i rehabilitanta/fizjoterapeuty (odpowiednio 50\% i 54\% poszukujących takich informacji). Szczegóły przedstawia rycina 2 i tabela III.

Zaobserwowano różnice w poziome satysfakcji zależnie od rozpoznania. Okazało się, że chorzy na nowotwory lite byli istotnie bardziej usatysfakcjonowani niż chorzy na nowotwory hematologiczne informacją otrzymaną od pracowników socjalnych $(\mathrm{t}=2,207 ; \mathrm{df}=45 ; \mathrm{p}=0,032)$, pracodawcy lub wychowawcy $(t=3,685 ; d f=22 ; p=0,001)$, grupy wsparcia ( $t=3,277 ; d f=50 ; p=0,002)$ i pielęgniarek $(t=2,252 ; d f=167 ; p=0,026)$.

W obu grupach badanych zanotowano, że emocje pozytywne znacząco dominowały nad emocjami negatywnymi. Zarówno na poziomie całej grupy $\left(\mathrm{M}_{\mathrm{e}-\mathrm{poz}}=29,33 \pm 7,91\right.$; $\left.M_{\text {e-neg }}=23,03 \pm 7,30 ; t=7,770 ; d f=218 ; p=0,000\right)$, jaki w grupie chorych na nowotwory lite $\left(\mathrm{M}_{\mathrm{e}-\mathrm{poz}}=29,58 \pm 8,73 ; \mathrm{M}_{\mathrm{e}-\mathrm{neg}}=\right.$ 21,$31 ; \pm 7,30 ; t=6,842 ; d f=110 ; p=0,000$ ) oraz nowotwory hematologiczne $\left(M_{e-p o z}=29,07 \pm 7,00 ; M_{e-n e g}=24,80 \pm 6,88\right.$; $\mathrm{t}=4,082 ; \mathrm{df}=108 ; \mathrm{p}=0,000)$ była to różnica istotna statystycznie. W obu grupach badanych emocje pozytywne przeważały nad negatywnymi, natomiast w grupie chorych na nowotwory hematologiczne znamiennie częściej niż w grupie chorych na nowotwory lite pojawiały się emocje negatywne ( $t=-3,637 ; \mathrm{df}=217 ; \mathrm{p}=0,000)$. Okazało się, że chorzy na nowotwory hematologiczne znamiennie częściej doświadczają takich emocji, jak: podekscytowanie, rozdrażnienie, poczucie winy, wrogie nastawienie, obawa, niepokój, poczucie beznadziejności, złość, zaś u chorych na nowotwory lite zdecydowanie dominowała chęć walki. Szczegóły dotyczące różnic między grupami przedstawia tabela IV.

Analiza wyników wykazała, że osoby, które uważają, że na co dzień mają wystarczającą możliwość poruszenia każdego tematu z najbliższą osobą, jak i te, które otwarcie rozmawiają z partnerami o tym, jaki wpływ ma choroba na ich wspólne życie, częściej niż pozostałe były zainteresowane otrzymaniem informacji od lekarzy. Z kolei chorzy, którzy byli bardziej zainteresowani poszukiwaniem informacji u psychologów, to osoby, które skarżyły się na: zwiększone ograniczenie w wykonywaniu codziennych czynności, strach przed ograniczeniami i utratą kontroli, poczucie zmniejszenia własnej atrakcyjności fizycznej, zmianę relacji z bliskimi, obniżenie nastroju. Osoby, które deklarowały zwiększenie religijności i wiary, miały mniejsze zapotrzebowanie na szukanie informacji u lekarzy, natomiast częściej szukały wiedzy i odpowiedzi na swoje pytania u pozostałych profesjonalistów i osób z otoczenia. Poza tym chorzy doświadczający więcej negatywnych emocji byli bardziej zainteresowani dostępem do psychologów i psychoterapeutów i częściej niż pozostałe osoby rozmawiali o chorobie z najbliższymi człon- 


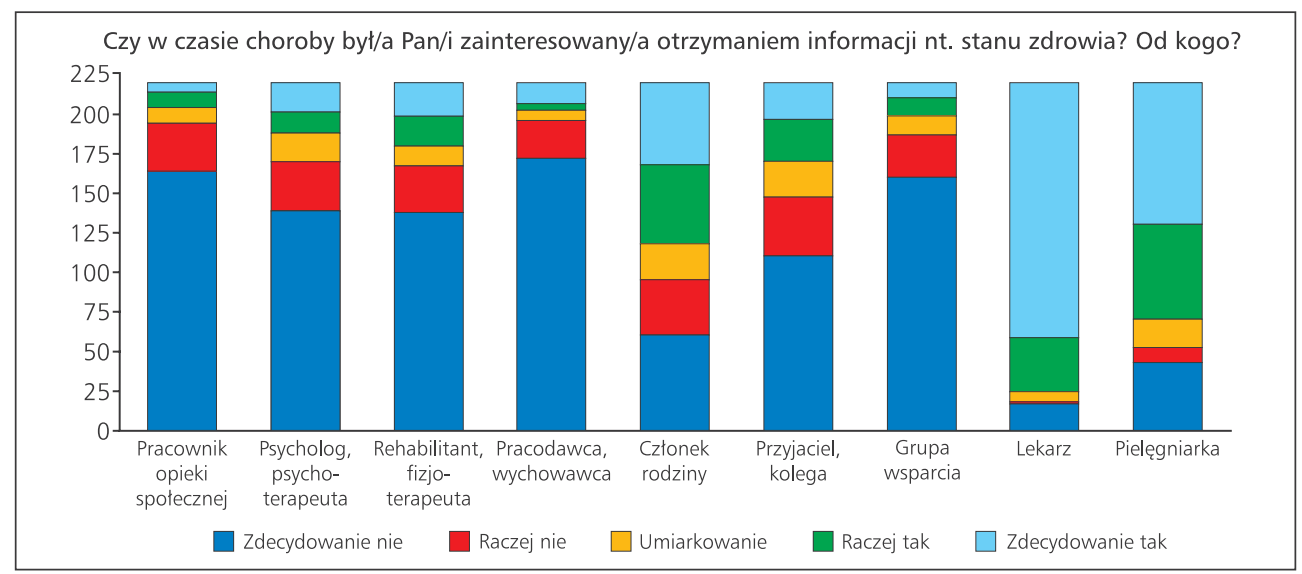

Rycina 1. Waga informacji nt. swojego stanu zdrowia i choroby od poszczególnych profesjonalistów i osób z otoczenia chorych na nowotwory

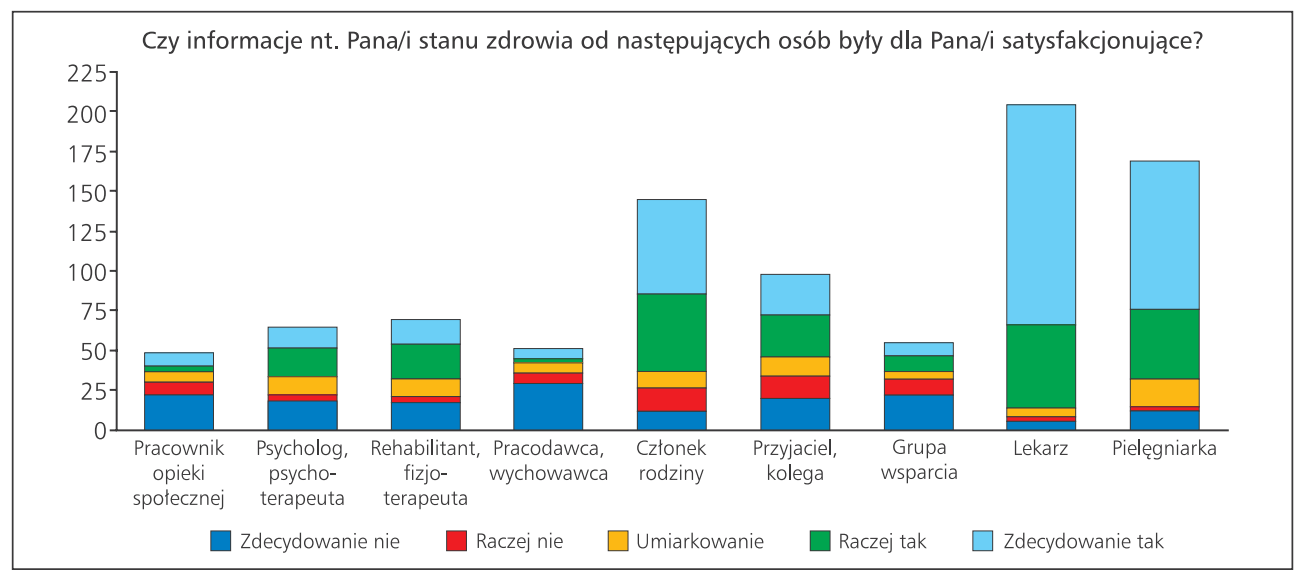

Rycina 2. Ocena satysfakcji z otrzymanej informacji nt. swojego stanu zdrowia i choroby od poszczególnych profesjonalistów i osób z otoczenia chorych na nowotwory przy uwzględnieniu stopnia zainteresowania chorych poszczególnymi źródłami informacji

Tabela III. Procentowa ocena satysfakcji z otrzymanej informacji nt. swojego stanu zdrowia i choroby od poszczególnych profesjonalistów i osób z otoczenia chorych na nowotwory

\begin{tabular}{|c|c|c|c|c|c|c|c|c|c|c|}
\hline & & $\begin{array}{c}\text { Pracownik } \\
\text { opieki } \\
\text { społecznej }\end{array}$ & $\begin{array}{c}\text { Psycholog, } \\
\text { psycho- } \\
\text { terapeuta }\end{array}$ & $\begin{array}{c}\text { Rehabilitant, } \\
\text { fizjotera- } \\
\text { peuta }\end{array}$ & $\begin{array}{l}\text { Pracodawca, } \\
\text { wychowawca }\end{array}$ & $\begin{array}{l}\text { Członek } \\
\text { rodziny }\end{array}$ & $\begin{array}{l}\text { Przyjaciel, } \\
\text { kolega }\end{array}$ & $\begin{array}{c}\text { Grupa } \\
\text { wsparcia }\end{array}$ & Lekarz & $\begin{array}{l}\text { Pielęg- } \\
\text { niarka }\end{array}$ \\
\hline \multirow{6}{*}{$\begin{array}{l}\text { Czy informacje } \\
\text { nt. Pana/Pani } \\
\text { stanu zdrowia } \\
\text { od następujących } \\
\text { osób były dla } \\
\text { Pana/Pani } \\
\text { satysfakcjo- } \\
\text { nujące: }\end{array}$} & zdecydowanie nie & $45 \%$ & $27 \%$ & $24 \%$ & $56 \%$ & $8 \%$ & $20 \%$ & $40 \%$ & $3 \%$ & $7 \%$ \\
\hline & raczej nie & $17 \%$ & $6 \%$ & $6 \%$ & $14 \%$ & $10 \%$ & $14 \%$ & $18 \%$ & $1 \%$ & $2 \%$ \\
\hline & umiarkowanie & $15 \%$ & $17 \%$ & $16 \%$ & $12 \%$ & $7 \%$ & $12 \%$ & $9 \%$ & $3 \%$ & $10 \%$ \\
\hline & raczej tak & $6 \%$ & $28 \%$ & $32 \%$ & $6 \%$ & $34 \%$ & $27 \%$ & $18 \%$ & $26 \%$ & $26 \%$ \\
\hline & zdecydowanie tak & $17 \%$ & $22 \%$ & $22 \%$ & $12 \%$ & $41 \%$ & $27 \%$ & $15 \%$ & $67 \%$ & $55 \%$ \\
\hline & Ogółem & $100 \%$ & $100 \%$ & $100 \%$ & $100 \%$ & $100 \%$ & $100 \%$ & $100 \%$ & $100 \%$ & $100 \%$ \\
\hline
\end{tabular}

kami rodziny, natomiast osoby, które doświadczały więcej pozytywnych emocji, częściej szukały informacji o swojej chorobie u przyjaciół i kolegów. Więcej informacji dotyczących związku pomiędzy występującymi trudnościami a poszukiwaniem informacji prezentuje tabela V i tabela VI.

Okazało się też, że jeśli ktoś szukał w ogóle informacji o chorobie, czy to u profesjonalisty, czy też u pozostałych osób z otoczenia chorego, to częściej miał tendencję do tego, by korzystać z wielu źródeł informacji.

\section{Dyskusja}

Osoby chore na nowotwór już od pierwszej wizyty w placówce medycznej, gdy pojawia się przypuszczenie niekorzystnej diagnozy, przez cały proces diagnostyczny i leczenie 
Tabela IV. Różnice średnich pomiędzy emocjami odczuwanymi w grupie chorych na nowotwory lite i nowotwory hematologiczne - w tabeli przedstawiono emocje, którymi osoby badane z obu grup różniły się w sposób istotny statystycznie

\begin{tabular}{|c|c|c|c|c|c|c|}
\hline Emocje & $\begin{array}{l}\text { Rodzaj choroby } \\
\text { nowotworowej }\end{array}$ & M & SD & $\mathrm{t}$ & df & $\mathrm{p}$ \\
\hline \multirow[t]{2}{*}{ Podekscytowany } & Nowotwory lite & 2,2613 & 1,04195 & $-2,424$ & 217 &, 016 \\
\hline & Nowotwory krwi & 2,5741 & ,85603 & & & \\
\hline \multirow[t]{2}{*}{ Rozdrażniony } & Nowotwory lite & 2,6126 & 1,09686 & $-2,852$ & 211,525 &, 005 \\
\hline & Nowotwory krwi & 3,0000 & 90688 & & & \\
\hline \multirow[t]{2}{*}{ Winny } & Nowotwory lite & 1,3604 & ,77216 & $-3,245$ & 212,215 &, 001 \\
\hline & Nowotwory krwi & 1,7222 & ,87364 & & & \\
\hline \multirow[t]{2}{*}{ Wrogo nastawiony } & Nowotwory lite & 1,3784 & 88476 & $-3,681$ & 215,243 &, 000 \\
\hline & Nowotwory krwi & 1,8333 & ,94226 & & & \\
\hline \multirow[t]{2}{*}{ Obawiam się } & Nowotwory lite & 2,3514 & 1,15718 & $-2,636$ & 215,181 &, 009 \\
\hline & Nowotwory krwi & 2,7407 & 1,02648 & & & \\
\hline \multirow[t]{2}{*}{ Odczuwam niepokój } & Nowotwory lite & 2,6486 & 1,18051 & $-3,061$ & 215,394 &, 002 \\
\hline & Nowotwory krwi & 3,1111 & 1,05311 & & & \\
\hline \multirow[t]{2}{*}{ Zestresowany } & Nowotwory lite & 2,5225 & 1,15874 & $-3,403$ & 217 &, 001 \\
\hline & Nowotwory krwi & 3,0370 & 1,07587 & & & \\
\hline \multirow[t]{2}{*}{ Chęć walki } & Nowotwory lite & 4,0180 & 1,20591 & 2,789 & 217 &, 006 \\
\hline & Nowotwory krwi & 3,5556 & 1,24805 & & & \\
\hline \multirow[t]{2}{*}{ Poczucie beznadziejności } & Nowotwory lite & 1,7748 & 1,04172 & $-2,675$ & 215 &, 008 \\
\hline & Nowotwory krwi & 2,1698 & 1,13366 & & & \\
\hline \multirow[t]{2}{*}{ Złość } & Nowotwory lite & 2,3514 & 1,10904 & $-2,755$ & 209,147 &, 006 \\
\hline & Nowotwory krwi & 2,7308 & 90555 & & & \\
\hline
\end{tabular}

Legenda: M — średnia, SD — odchylenie standardowe, $\mathrm{t}$ — statystyka t-Studenta, df — stopnie swobody, p — poziom istotności

aż do rekonwalescencji lub zakończenie leczenia narażone są na psychiczny dystres i stają w obliczu dużych znaków zapytania dotyczących ich zdrowia i życia. Próbują odnaleźć się w systemie i niewątpliwie chcieliby otrzymać najlepszą opiekę i leczenie. Osoby, u których stwierdzono nowotwór i które rozpoczynają terapię onkologiczną, zazwyczaj nie posiadają wiedzy medycznej i dostatecznych informacji o chorobie i leczeniu. Wydawałoby się, że zrobią zatem wszystko, by dotrzeć do rzetelnego źródła informacji i otrzymać od osób lub instytucji te informacje, które są dla nich ważne i potrzebne, by diagnostyka i leczenie przebiegały sprawnie i same w sobie nie były źródłem niepewności i stresu. Wyniki przeprowadzonego badania wskazują jednak, że chorzy nie zawsze wiedzą, do kogo mogą zwrócić się o informacje i pomoc. Co prawda, prawie wszyscy respondenci (90\%) byli zainteresowani otrzymaniem informacji od lekarza i ponad dwie trzecie badanych (68\%) z pytaniami również zwracało się do pielęgniarki, ale już z pomocy w zdobywaniu informacji od pracodawcy/wychowawcy, pracownika socjalnego i psychologa/psychoterapeuty korzystali bardzo rzadko (odpowiednio 7\%, 8\% i 15\% badanych). Lekarze i pielęgniarki są właściwym i najpopularniejszym źródłem informacji, ale należy wziąć pod uwagę, że to źródło dość ograniczone z powodu zasobów - liczebnych i czasowych. Wystarczy wspomnieć, że według danych z Ministerstwa Zdrowia, opracowanych na podstawie rocznych sprawozdań konsultantów krajowych w poszczególnych dziedzinach, wynika, że aktualnie w Polsce mamy 456 lekarzy onkologów klinicznych i 315 hematologów (w tym 1/3 w trakcie specjalizacji) [11]. Dane z Naczelnej Izby Lekarskiej z 2010 r. wskazują, że w zakresie chirurgii onkologicznej aktywnych jest 546 specjalistów, ginekologii onkologicznej - 102, medycyny paliatywnej - 214, onkologii i hematologii dziecięcej 133, zaś radioterapii onkologicznej - 484 [12]. Bez wątpienia nie są to zasoby specjalistów, które mogłyby w pełni zabezpieczyć potrzeby pozamedyczne chorych na nowotwory. Można byłoby w takim razie założyć, że chorzy powinni, w dobrze pojętym swoim interesie, szukać dostępu do innych specjalistów i źródeł informacji. Okazuje się tymczasem, że zdecydowana większość z nich nie szuka informacji ani u psychologów/psychoterapeutów, ani u rehabilitantów/fizjoterapeutów czy też pracowników socjalnych. Wyżej wymienieni specjaliści są, przynajmniej w pewnym wymiarze, dostępni w ośrodkach onkologicznych. Podobnie prawie trzy czwarte chorych nie poszukuje informacji w grupach wsparcia i organizacjach pacjenckich. Organizacje te mogłyby okazać się przecież bardzo pomocne, gdyż zrzeszają osoby chore lub już po przebytym leczeniu onkologicznym, które mogłyby i są gotowe podzielić się swoim własnym doświadczeniem z procesu diagnostyki i leczenia, udzielić 


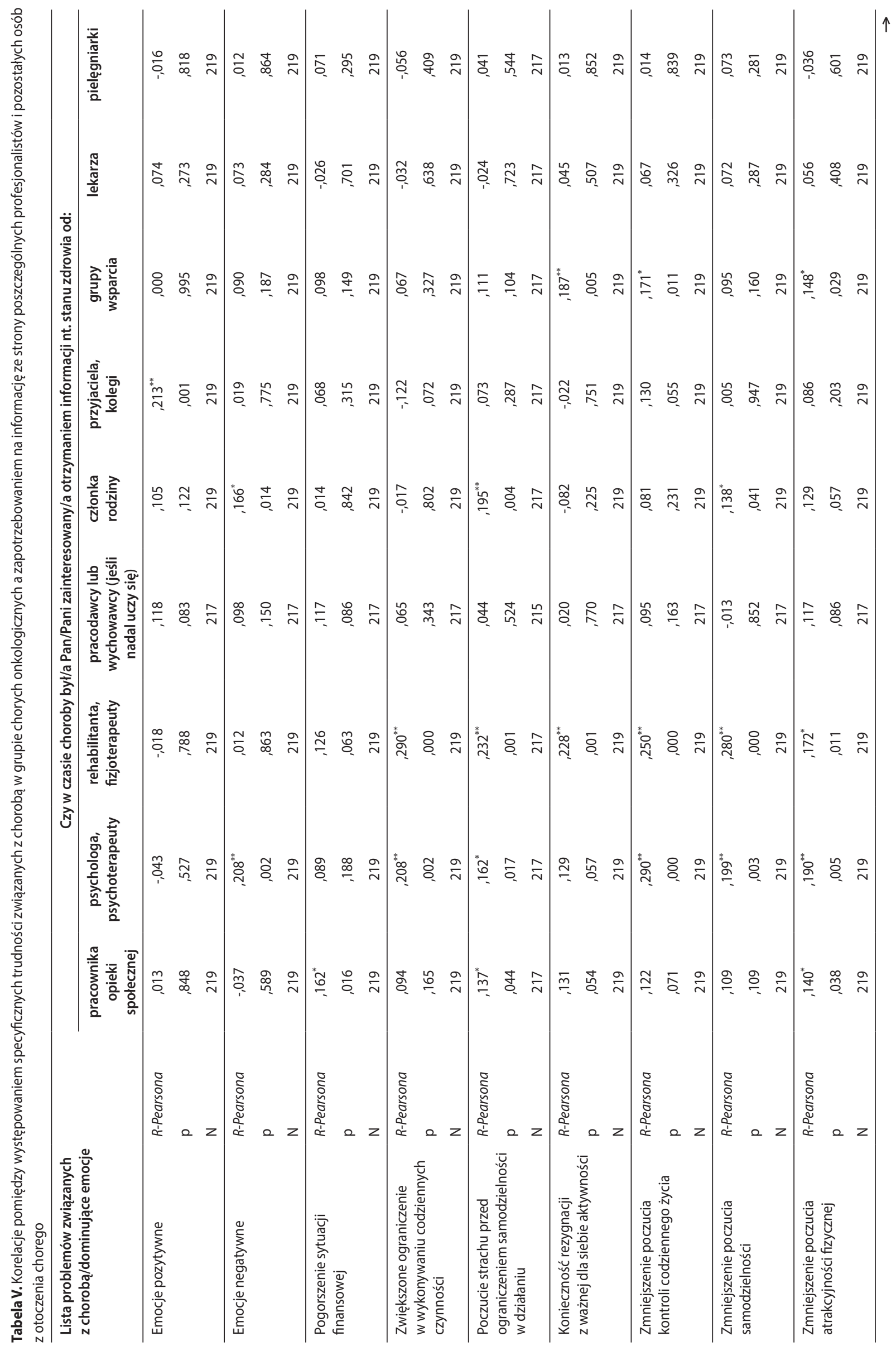




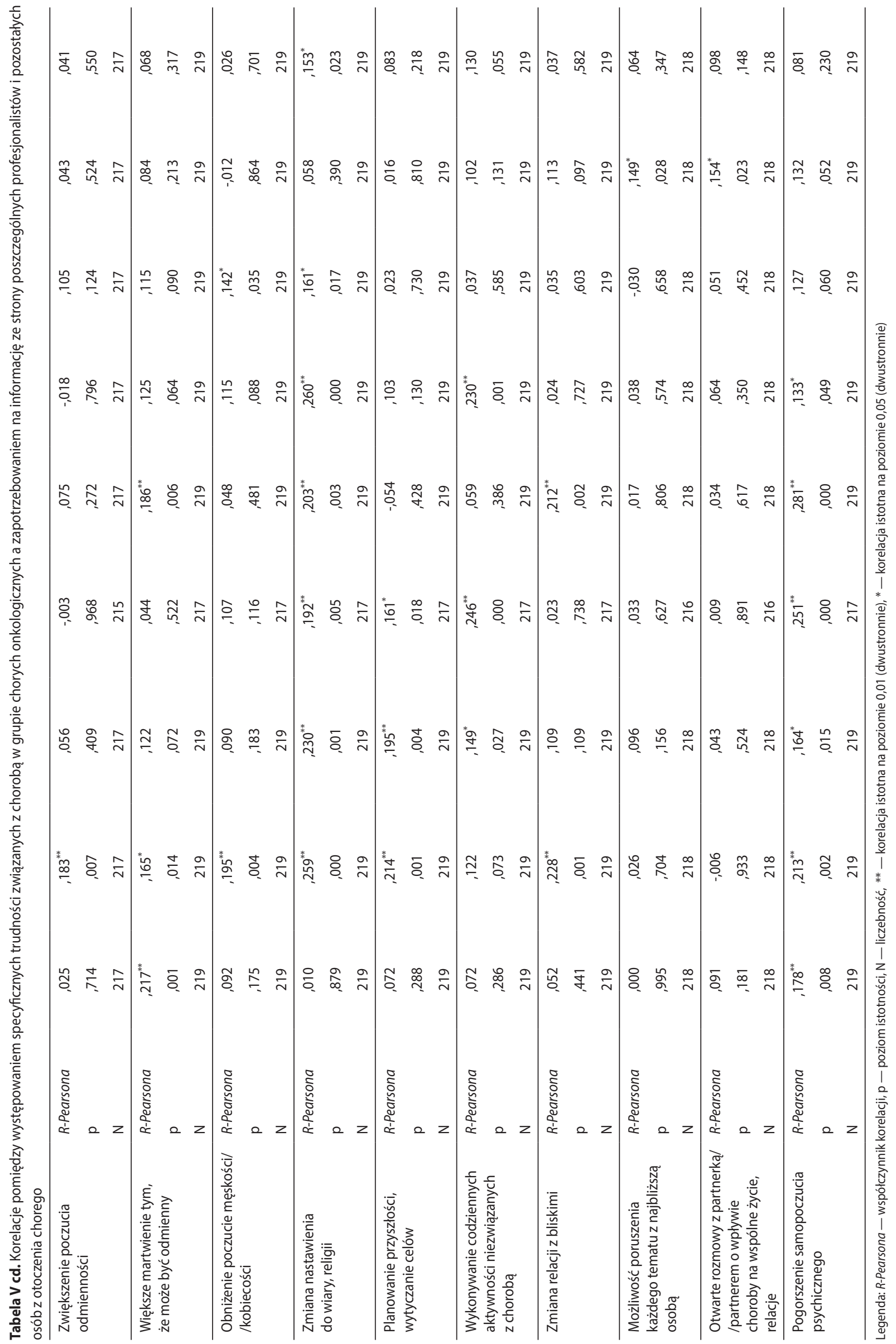




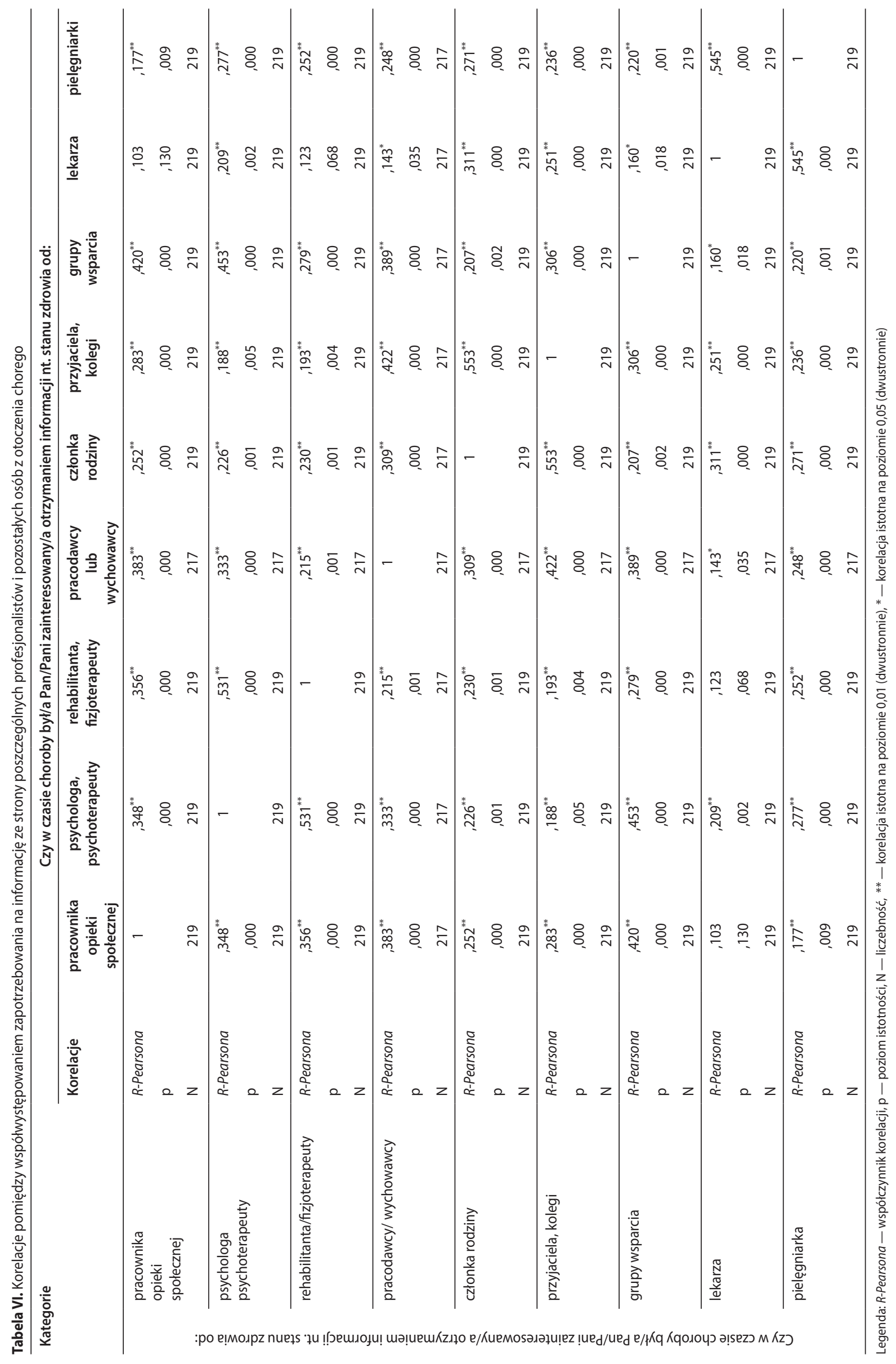


rad i wsparcia. Brak sięgania po informacje z innych źródeł niż lekarze i pielęgniarki powoduje, że chorzy na nowotwory doświadczają więcej dystresu i negatywnych emocji niż można byłoby przypuszczać. W badanej grupie zaobserwowaliśmy, że chorzy na nowotwory hematologiczne doświadczają więcej emocji negatywnych, szczególnie wyrażających się poczuciem beznadziejności, poczuciem winy, ale również rozdrażnieniem czy złością. Niewykluczone, że część z tych emocji wynika z konfrontacji z systemem opieki zdrowotnej i subiektywnie odczuwanej ograniczoności jego zasobów. Możliwe, że w przypadku częstszego kontaktu z innymi profesjonalistami (poza lekarzami i pielęgniarkami) ich frustracje, obawy i wrogie nastawienie byłyby mniejsze, a emocje bardziej pozytywne.

Wysoki poziom satysfakcji chorych z dostępu do informacji dotyczył przede wszystkim ich kontaktów z lekarzami i pielęgniarkami. Pacjenci nie byli natomiast usatysfakcjonowani informacjami uzyskiwanymi od pozostałych profesjonalistów. Biorąc pod uwagę powyższe wyniki, jak i międzynarodowe oraz krajowe zalecenia opieki koordynowanej [13], wydaje się, iż taki model byłby bardziej przyjazny dla pacjentów - dawałby bowiem lepszy dostęp do informacji z różnych źródeł, odciążałby lekarzy i pielęgniarki, równocześnie dając pacjentowi satysfakcjonujące kontakty z innymi profesjonalistami pozostającymi w tym samym zespole. Oczywiście i tu należy zwrócić uwagę na dostępność zasobów osobowych i ewentualne braki. Jednym z ważniejszych filarów dobrej, nowoczesnej opieki onkologicznej jest m.in. psycholog (najlepiej psychoonkolog) lub psychoterapeuta. Tymczasem z informacji z 2006 roku wynika, że na 40 większych jednostek onkologicznych istniejących w Polsce, spośród których na ankietę odpowiedziało 30 jednostek, 20 jednostek zatrudniało w sumie 20 psychologów i 10 psychiatrów, a aż 10 jednostek nie miało w zespole żadnego psychoonkologa [14]. Oznaczało to, że prawie połowa chorych na nowotwory nie miała w ogóle dostępu (szczególnie w leczeniu ambulatoryjnym) do profesjonalnej opieki psychologicznej. W chwili obecnej certyfikowanych przez Polskie Towarzystwo Psychoonkologiczne psychoonkologów jest w kraju 94. Ponadto, biorąc pod uwagę wymogi NFZ i warunki dodatkowe, jakie muszą spełniać oddziały onkologii klinicznej, oddziały hematologii, jak i chirurgii onkologicznej, zatrudniając psychologów przynajmniej w wymiarze 20 godzin tygodniowo, dostęp do profesjonalnej opieki psychologicznej znacznie się polepszył, choć nadal nie jest to wszechobowiązujący standard.

Obserwacje dokonane na podstawie własnego doświadczenia klinicznego, a także wyniki badania wskazują, że pacjenci nie szukają aktywnie informacji i wsparcia, nie wiedzą też, jakiej pomocy mogliby szukać i kogo o nią prosić. Jeśli już w ogóle odważą się zadawać dodatkowe pytania, to najczęściej kierują je do lekarzy i personelu pielęgniarskie- go, gdyż te osoby zwykle są w pobliżu i w stałym kontakcie z pacjentami. Wydaje się, iż konieczne jest tworzenie wielodyscyplinarnych zespołów opieki i wsparcia działających na terenach ośrodków onkologicznych, dokładne informowanie pacjentów o możliwości zwracania się z konkretnymi pytaniami i problemami do poszczególnych osób. Niezbędne jest także specjalistyczne szkolenie poszczególnych członków zespołu w umiejętnościach nawiązywania dobrych profesjonalnych kontaktów z pacjentami, tak aby chorzy mogli uzyskiwać jak największą korzyść z ich wsparcia. Prawdopodobnie przełożyłoby się to na zmniejszenie dystresu chorych na nowotwory i poprawiło ich jakość życia.

\section{Konflikt interesów: nie zgłoszono}

\section{Dr n. med. Anna Kieszkowska-Grudny}

Europejskie Centrum Zdrowia

ul. Borowa 14/18, 05-400 Otwock

e-mail:anna.kieszkowska@gmail.com

Otrzymano: 5 maja 2015 r.

Przyjęto do druku: 2 czerwca 2015 r.

\section{Piśmiennictwo}

1. Raport WHO. 2013. GLOBOCAN 2012. http://www.iarc.fr/en/media-centre/pr/2013/pdfs/pr223 E.pdf [data odczytu:02.07.2014].

2. Bultz BD, Holland JC. Emotional distress in patients with cancer: the sixth vital sign. Community Oncology 2006; 3: 311-314.

3. Holland J. Fears and abnormal reactions to cancer in physically healthy indyviduals. W: Holland J, Rowland J (red.) Handbook of Psychooncology. New York: Oxford Univ Press, 1990; 7-21.

4. Jokiel M, Bielska-Lasota M, Wronkowski Z. Zmiany uświadomienia i zachowań zdrowotnych kobiet dotyczące profilaktyki raka szyjki macicy w latach 1976, 1986, 1990 i 1998. Przegl Epidemiol 2001; 55: 323-330.

5. Eheman CR, Berkowitz Z, Lee J i wsp. Information-seeking styles among cancer patients before and after treatment by demographics and use of information sources. J Health Commun 2009; 14: 487-502.

6. Nagler RH, Gray SW, Romantan A i wsp.. Differences in information seeking among breast, prostate, and colorectal cancer patients: results from a population-based survey. Patient Educ Couns 2010; 81 Suppl: S54-62.

7. Kosowicz M. Psychoedukacja pacjenta onkologicznego. Akademia onkologii i hematologii. Dostępne na stronie www.ofe.edu.pl.

8. Chojnacka-Szawłowska G. Wiedza o symptomach nowotworowych pacjentów poddawanych diagnostyce onkologicznej a stopień klinicznego zaawansowania choroby. Psychoonkologia 1998; 2: 27-36.

9. Devine EC, Westlake SK. The effects of psychoeducational care provided to adults with cancer: meta-analysis of 116 studies. Oncology Nursing Forum 1995; 22: 1369-1381.

10. Richardson MA, Sanders T, Palmer JL i wsp. Complementary/alternative medicine use in a comprehensive cancer center and the implications for oncology. J Clin Oncol 2000, 18: 2505-2514.

11. Ministerstwo Zdrowia. 2014. Specjalizacje lekarskie w Polsce. Stan obecny, perspektywy rozwoju w latach 2010-2015. [data odczytu: 01.03.2015]

12. Biała Ksiega. 2011. Zwalczanie raka jelita grubego i raka piersi w Polsce na tle wybranych krajów europejskich. Analiza zasobów systemu opieki onkologicznej i czynników warunkujących sukces. Ośrodek Analiz Uniwersyteckich, Warszawa-Kraków. http://www.walkazrakiem.pl/sites/default/files/library/files/biala_ksiega.pdf [data odczytu: 28.06.2014].

13. Kowalska K, Kalbarczyk WP. Koordynowana opieka zdrowotna. Do świadczenia międzynarodowe, propozycje dla Polski. Sprawne Państwo. Program EY. Warszawa, 2013.

14. Walden-Gałuszko K. Psychoonkologia dzisiaj: gdzie jesteśmy — dokąd zmierzamy? Psychoonkologia 2006; 10: 1-2. 